\title{
Effect of eugenol on animal models of nociception
}

\author{
R. Kurian, D. K. Arulmozhi, A. Veeranjaneyulu, S. L. Bodhankar
}

\author{
Department of Pharmacology, \\ Bharati Vidyapeeth Deemed \\ University, \\ Poona College of Pharmacy, \\ Pune 411038. \\ *Present Address: Discovery \\ Biology, Advinus Therapeutics, \\ Bioresearch Centre, \\ Pune 411057, \\ Maharashtra, India. \\ Received: 31.3 .2006 \\ Revised: 28.6.2006 \\ Accepted: 3.7.2006 \\ Correspondence to: \\ S.L. Bodhankar \\ E-mail: sbodh@yahoo.com
}

\begin{abstract}
Objective: To investigate the antinociceptive potential of eugenol on different pain models in mice.

Materials and Methods: Eugenol was evaluated (1-100 mg/kg, i.p.) in various experimentally induced pain models like, formalin induced hyperalgesia, acetic acid induced abdominal constrictions, and thermal pain experiment using Eddy's hot plate. Results: Eugenol significantly inhibited acetic acid induced abdominal constrictions, with the maximal effect $(92.73 \%$ inhibition) at $100 \mathrm{mg} / \mathrm{kg}$. In formalin induced paw licking pain model, eugenol exhibited more pronounced antinociceptive effect in the inflammatory phase than the neurogenic phase (maximal effect was $70.33 \%$ and $42.22 \%$, respectively, at $100 \mathrm{mg} / \mathrm{kg}$, i.p). A mild reduction in the pain response latency at 100 $\mathrm{mg} / \mathrm{kg}$, i.p. dose of eugenol was observed in the hotplate thermal pain studies in mice. In the rotarod motor coordination experiment eugenol reduced the endurance time at the dose of $100 \mathrm{mg} / \mathrm{kg}$, i.p.

Conclusion: The data suggest that eugenol exerts antinociceptive activity in different experimental models of pain in mice.
\end{abstract}

KEYWORDS: Antinociceptive, clove oil, pain models.

\section{Introduction}

Eugenol (4-allyl-2-methoxyphenol), the principal chemical constituent of clove oil has been primarily derived from a variety of plant sources, including Eugenia caryophyllus and Myristica fragrans. For years eugenol has been used in dental practice to relieve pain arising from a variety of sources, including pulpitis and dentinal hypersensitivity. In the recent past, a wealth of literature has been generated on eugenol's antidepressant, antistress, anticonvulsant, and analgesic activities. ${ }^{[1-3]}$ Eugenol is also reported to possess antiinflammatory, antioxidant, anaesthetic and muscle relaxant properties. ${ }^{\mid 4-6]}$

The objective of the present investigation was to study a range of doses of eugenol (from 1 to $100 \mathrm{mg} / \mathrm{kg}$ ) towards possible analgesic potential in both peripheral and central experimental pain models.

\section{Materials and Methods}

\section{Chemicals}

Eugenol and indomethacin were purchased from Sigma Chemical Co. (St. Louis, USA). Pentazocine lactate (Fortwin ${ }^{\circledR}$ Ranbaxy, India) and diazepam (Calmpose ${ }^{\circledR}$ Ranbaxy, India) were obtained as injections from local market. Eugenol and indomethacin were dissolved in $0.5 \%$ Tween 80 in saline. Pentazocine and diazepam were diluted with saline.

\section{Animals}

Adult male Swiss albino mice (22-26 g) were obtained from the National Toxicology Centre, Pune, India. The animals were randomly allocated to treatment groups (six animals per group, per treatment) in polypropylene cages with paddy husk as bedding. Animals were housed at a temperature of $24 \pm 2^{\circ} \mathrm{C}$ and relative humidity of 30 to $70 \%$. A 12:12 light:dark cycle was followed. All animals had free access to water and standard pelleted laboratory animal diet. All the experimental protocols were approved by the Institutional Animal Care and Use Committee of Poona College of Pharmacy, Pune, India and were in accordance with the guidelines of the Committee for the Purpose of Control and Supervision of Experiments on Animals (CPCSEA), Ministry of Forests and Environment, Government of India. Rules of the CPCSEA are based on ILAR (Institute of Laboratory Animal Resources, USA) guidelines.

\section{Acetic acid induced abdominal constrictions in mice}

The i.p. injection of acetic acid (1\%), resulted in constriction of abdominal muscle together with a stretching of hind limbs. This procedure was carried out as described by Santos et al ${ }^{[7]}$ Eugenol (1-100 mg/kg) and positive control indomethacin (20 $\mathrm{mg} / \mathrm{kg}$ ) were administered i.p., 15 min prior to acetic acid injection. The number of writhing movements was counted for $30 \mathrm{~min}$, from the time immediately after acetic acid injection. Antinociception was expressed as the number of abdominal 
constrictions between saline treated control and animals pretreated with eugenol or indomethacin.

Formalin induced paw licking in mice

This procedure was essentially similar to that described by Hunskaar and Hole. ${ }^{[8]}$ Mice were injected intraperitoneally with eugenol $(1-100 \mathrm{mg} / \mathrm{kg})$ or $0.5 \%$ Tween $80(10 \mathrm{ml} / \mathrm{kg})$ or indomethacin $(20 \mathrm{mg} / \mathrm{kg})$. Fifteen minutes later $20 \mu \mathrm{l}$ of $1 \%$ formalin was injected subcutaneously under the dorsal surface of the hind paw, and the animals were observed in the chambers. The time spent for licking the paw injected with formalin was counted for $30 \mathrm{~min}$ post formalin injection and considered as indicative of pain stimuli. The formalin test had two distinctive phases, possibly reflecting different types of pain. The first phase of the nociceptive response normally peaked at $5 \mathrm{~min}$ and the second phase 20 to $30 \mathrm{~min}$ after formalin injection. This represented neurogenic and inflammatory responses, respectively.

Hot plate test in mice

The hot plate test was carried out according to the method described by Eddy and Leimbach. ${ }^{[9]}$ Animals were placed on the hot plate (Ugo Basile, Italy) maintained at $55 \pm 1^{\circ} \mathrm{C}$ and the time between placement on the hot plate and the occurrence of either licking of the paws, shaking, or jumping off from the plate was recorded as response latency. Mice with basal latency of more than $10 \mathrm{sec}$ were not included in the study. The response latencies was measured before distraction (basal) and after drug treatment [eugenol (1-100 mg/kg, i.p.) or 0.5\% Tween $80(10 \mathrm{ml} / \mathrm{kg}$, i.p.) or pentazocine $(10 \mathrm{mg} / \mathrm{kg}$, i.p. $)]$ at $30,60,90,120$ and $180 \mathrm{~min}$. The cut off time for hot plate latency was set at $20 \mathrm{sec}$.

Motor coordination (rotarod test) in mice

A rotarod tread mill device (Techno, India) was used for the evaluation of motor coordination. Mice were placed on a horizontal rotating (16 RPM) rod. These mice had been selected for their ability to remain on the revolving bar for a 2 min period. Fifteen minutes after the administration of either eugenol (30 and $100 \mathrm{mg} / \mathrm{kg}$, i.p.) or diazepam (5 mg/kg, i.p.), each mouse was placed on the rotating rod for $60 \mathrm{sec}$, at intervals of $30 \mathrm{~min}$ for $3 \mathrm{~h} .{ }^{[10]}$ The endurance time for each mouse on the rota-rod was noted.

Statistical analysis

Values are expressed as mean \pm SEM. The statistical significance of difference between the means was analysed by one-way non-parametric ANOVA and Dunnett's test. $P<0.05$ was considered significant. All the statistical manipulations were carried out using GraphPad ${ }^{\circledR}$ Prism Software (Graphpad Software Inc., USA).

\section{Results}

\section{Acetic acid induced abdominal constrictions in mice}

The results of the abdominal constriction test are shown in Figure 1. Eugenol elicited a dose-dependent inhibition of abdominal constrictions compared with the control group. Eugenol produced $10.61 \%$ inhibition at $1 \mathrm{mg} / \mathrm{kg}$ dose, with a maximal of inhibition $92.73 \%(P<0.001 ; \mathrm{F}=8.20)$ at $100 \mathrm{mg} /$ $\mathrm{kg}$, which was comparable to indomethacin $(93.64 \%$ inhibition at $20 \mathrm{mg} / \mathrm{kg}$, i.p.).

\section{Formalin induced paw licking in mice}

Eugenol exhibited no effect during the neurogenic phase
(0-10 min) of formalin induced licking in mice at $1 \mathrm{mg} / \mathrm{kg}$, $11.67 \%$ inhibition at $10 \mathrm{mg} / \mathrm{kg}$, i.p., and $42.22 \%$ at $100 \mathrm{mg} / \mathrm{kg}$ $(P<0.001 ; \mathrm{F}=5.30)$ compared with the vehicle treated animals. The standard, indomethacin $(20 \mathrm{mg} / \mathrm{kg})$ caused $63.93 \%$ inhibition. [Figure 2]

A mild inhibitory effect (3.14\%) with eugenol on the inflammatory phase (20 to $30 \mathrm{~min}$ ) of the formalin induced paw licking in mice was observed at $1 \mathrm{mg} / \mathrm{kg}$, and a statistically significant maximal inhibition (70.33\% inhibition) was observed at $100 \mathrm{mg} / \mathrm{kg}(P<0.05 ; \mathrm{F}=5.69)$. The standard drug, indomethacin $(20 \mathrm{mg} / \mathrm{kg})$, also exhibited a statistically significant inhibition (66.18\%) of the inflammatory phase. [Figure 3]

Figure 1. Effect of eugenol on acetic acid induced abdominal constrictions in mice.

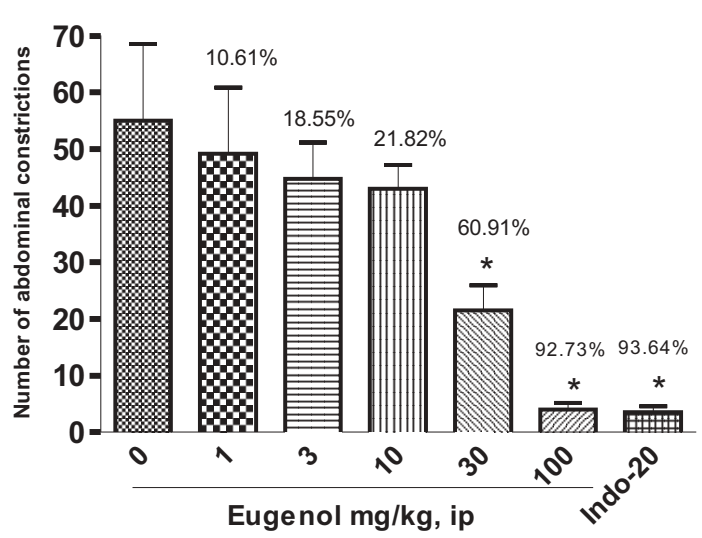

$\mathrm{n}=6$ in each group. The bars represent mean \pm SEM and the percentages indicate \%inhibition. ${ }^{*} P<0.005$ compared with vehicle treatment. Indo: indomethacin.

Figure 2. Effect of eugenol on neurogenic phase of formalin induced licks in mice.

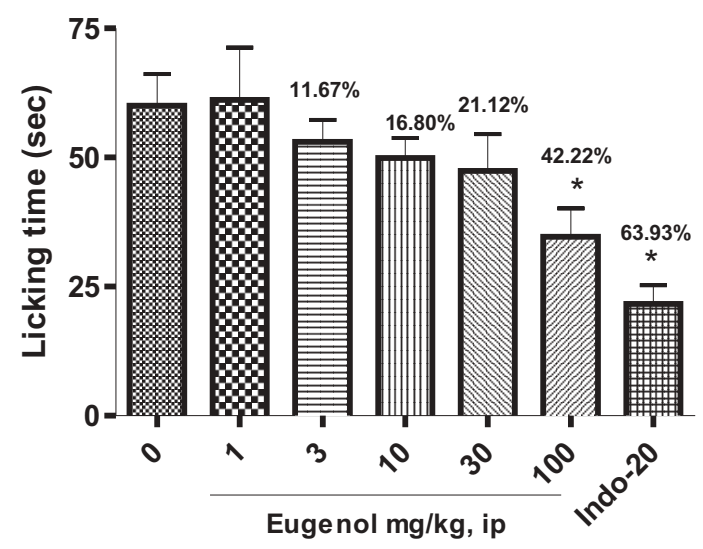

$\mathrm{n}=6$ in each group. The bars represent mean+SEM and the percentages indicate \%inhibition. ${ }^{*} P<0.005$ compared with vehicle treatment. Indo: indomethacin. 
Figure 3. Effect of eugenol on inflammatory phase of formalin induced licks in mice.

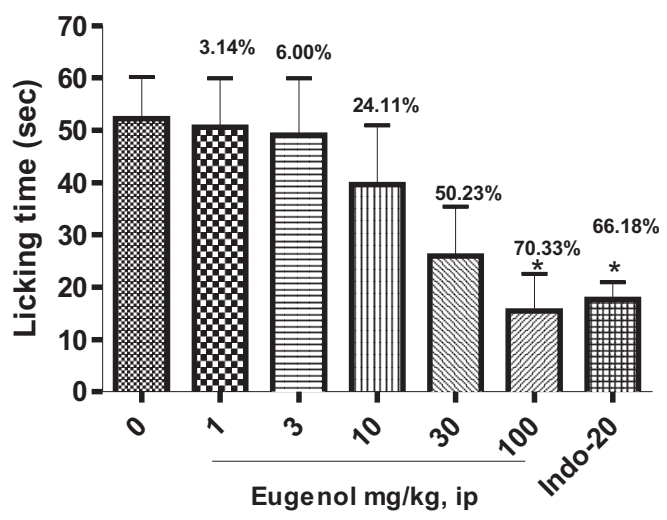

$\mathrm{n}=6$ in each group. The bars represent mean \pm SEM and the percentages indicate \%inhibition. ${ }^{*} P<0.005$ compared with vehicle treatment. Indo: indomethacin.

\section{Hot plate test in mice}

Eugenol (1 to $100 \mathrm{mg} / \mathrm{kg}$ ) pretreatment increased the response latency in the hot plate test. This, however, was not statistically significant. The centrally acting analgesic pentazocine also increased the response latencies at various time points.

Figure 4. Effect of eugenol on motor coordination test in mice.

\section{Motor coordination in mice}

Eugenol administered intraperitoneally at $30 \mathrm{mg} / \mathrm{kg}$ did not affect motor coordination. A dose of $100 \mathrm{mg} / \mathrm{kg}$, however, produced a statistically insignificant reduction in the endurance time at 60 minutes. The standard drug, diazepam at $5 \mathrm{mg} / \mathrm{kg}$, i.p. dose exhibited a statistically significant $(P<0.05)$ effect on motor coordination by reducing the endurance time at the various times points. [Figure 4]

\section{Discussion}

In the present investigation, eugenol was studied for its nociceptive activity in both peripheral and central algesic models. This study differs from the earlier reports on the analgesic activity of eugeno[ ${ }^{[11,12]}$ primarily with respect to the route of administration, the doses employed, and the source of eugenol.

The intensity of analgesic effect of eugenol at $100 \mathrm{mg} / \mathrm{kg}$ dose was similar to that of indomethacin $(20 \mathrm{mg} / \mathrm{kg}$, i.p. $)$ in acetic acid induced abdominal constrictions in mice. Acetic acid causes inflammatory pain by inducing capillary permeability ${ }^{[13 \mid}$ and liberating endogenous substances that excite pain nerve endings. ${ }^{[14]}$ NSAIDs can inhibit COX in peripheral tissues and, therefore, interfere with the mechanism of transduction of primary afferent nociceptors. ${ }^{[15]}$ The mechanism of analgesic effect of eugenol could probably be due to blockade of the effect or the release of endogenous substances that excite pain nerve endings similar to that of

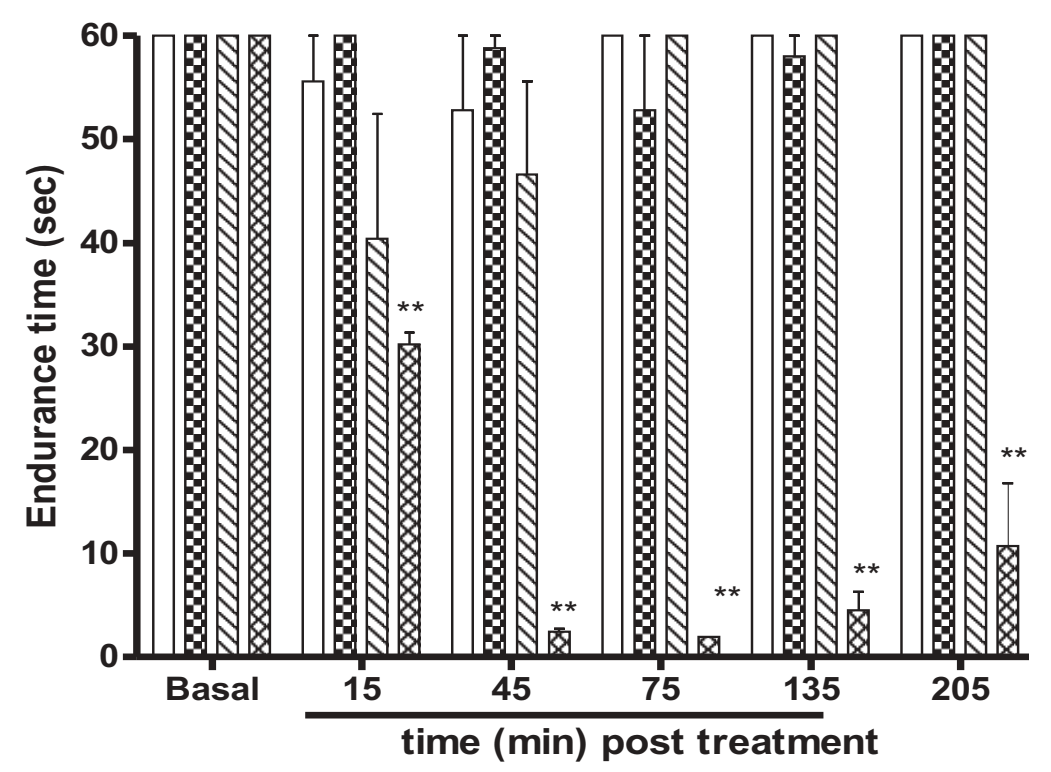

\footnotetext{
Vehicle $10 \mathrm{ml} / \mathrm{kg}$, i.p.

$\mathbf{K}$ Eugenol $30 \mathrm{mg} / \mathrm{kg}$,i.p. Miv Eugenol $100 \mathrm{mg} / \mathrm{kg}$,i.p. Diazepam - 5 mg/kg,i.p
}

$\mathrm{n}=6$ in each group. Values are mean \pm SEM. ${ }^{*} P<0.001$ compared with vehicle treatment. Each mouse was placed on the rotating rod for $60 \mathrm{sec}$. 
indomethacin and other NSAIDs. Recently, eugenol and its derivatives have been reported to exert inhibitory effect on various mediators of inflammation. This includes inhibition of lipopolysaccharide-stimulated nuclear factor kappa B activation and cyclooxygenase- 2 expression in macrophages. ${ }^{\mid 16,17]}$

Eugenol exhibited an efficacy comparable to that of indomethacin in inhibiting neurogenic (first phase) and inflammatory (second phase) pain stimuli caused by formalin. The formalin test is used to evaluate the mechanism by which an animal responds to moderate, continuous pain generated by the injured tissue. ${ }^{[18]}$ This test is characterised by two phases. The early phase (immediately after injection) seems to be caused by C-fibre activation due to the peripheral stimulus. The late phase (starting approximately 20 min after formalin injection) appears to depend on the combination of an inflammatory reaction, activation of NMDA and non-NMDA receptors, and the NO cascade ${ }^{[19]}$ in the peripheral tissue and functional changes in the dorsal horn of the spinal cord. ${ }^{[18]}$ Both these functional changes appear to be initiated by the C-fibre barrage during the early phase and to be related to excitatory amino acid (EAA) release in the spinal cord and activation of NMDA receptor subtypes. The formalin test has been used to evaluate the antinociceptive effects of competitive and non-competitive NMDA receptor antagonists administered intrathecally and systemically. ${ }^{[20]}$ CGP 37849, memantine, ketamine and dextromethorphan were reported to have antinociceptive activity in formalin test ${ }^{[21]}$

Although a wealth of literature is available on the inhibitory effect of eugenol on prostaglandin bio-synthesis and or nerve conduction as shown in the rat vagus nerve, ${ }^{|22|}$ there has been a recent upsurge in the research focus on the role of vanilloid receptors and calcium channels in the antinociceptive action of eugenol.

In a comparative study of $\beta$-caryophyllene oxide, eugenol, and nifedipine it was reported that eugenol blocked calcium channels. This was demonstrated in voltage clamp experiments in cardiac myocytes. ${ }^{|23|}$ In cell lines stably expressing human N-type calcium channels, eugenol reportedly inhibited highvoltage-activated calcium currents. ${ }^{\mid 24]}$

The role of vanilloid receptor in the antinociceptive activity of eugenol becomes evident from the studies conducted by Yang et al. ${ }^{25]}$ In vanilloid receptor 1 (TRPV1 or VR1), expressing human embryonic kidney (HEK) 293 cells and trigeminal ganglion neurons, eugenol activated inward currents while capsazepine, a competitive vanilloid receptor antagonist, completely blocked eugenol induced inward currents. This experiment supports the in vivo studies carried out by Ohkubo and Shibata ${ }^{[26]}$ who demonstrated the inhibitory effect of capsazepine on eugenol induced antinociceptive activity in mice. These studies provide strong evidence that eugenol produces its antinociceptive effects through different mediators and, at least in part, via blockade of calcium channels and vanilloid receptor modulation.

Eugenol produced antinociception against thermal induced pain stimuli in mice at various time points post treatment. The effect observed was, however, very mild and not statistically significant. The hot plate test is considered to be selective for opioid-like compounds, which are centrally acting analgesics in several animal species. ${ }^{[27]}$ In motor coordination test using rotarod apparatus, eugenol at 100 $\mathrm{mg} / \mathrm{kg}$, i.p. exhibited an insignificant sedative effect that was evidenced by reduction in endurance time. This could be the possible explanation for its mild central analgesic activity observed in hot plate test.

\section{Conclusion}

Eugenol administered intraperitoneally exhibits antinociceptive activity and possibly exerts its effect through diverse mechanisms that may involve both central and peripheral pathways. Present data support the traditional application of eugenol as a dental analgesic. Further pharmacodynamic investigations are required to understand the precise mechanism of antinociception exhibited by eugenol.

\section{Acknowledgments}

We thank Dr. S.S. Kadam and Dr. K.R. Mahadik (Bharati Vidyapeeth Deemed University, Poona College of Pharmacy, Pune) for their constant encouragement in the work.

\section{References}

1. Prakash P, Gupta N. Therapeutic uses of Ocimum sanctum Linn (Tulsi) with a note on eugenol and its pharmacological actions: a short review. Indian J Physiol Pharmacol 2005;49:725-31.

2. Irie $\mathrm{Y}$, Itokazu N, Anjiki N, Ishige A, Watanabe K, Keung WM. Eugenol exhibits antidepressant-like activity in mice and induces expression of metallothionein-III in the hippocampus. Brain Res 2004;1011:243-6.

3. Dallmeier Zelger KR, Zelger JL, Carlini EA. New anticonvulsants derived from 4-allyl-2-methoxyphenol (Eugenol): Comparison with common antiepileptics in mice. Pharmacology 1983;27:40-9.

4. Sell $A B$, Carlini EA. Anesthetic action of methyleugenol and other eugenol derivatives. Pharmacology 1976;14:367-77.

5. Ko FN, Liao $\mathrm{CH}$, Kuo $\mathrm{YH}$, Lin YL. Antioxidant properties of demethyldiisoeugenol. Biochim Biophys Acta 1995;1258:145-52.

6. Dohi T, Anamura S, Shirakawa M, Okamoto H, Tsujimoto A. Inhibition of lipoxygenase by phenolic dental medicaments. Jpn J Pharmacol 1991;55:54750 .

7. Santos ARS, Filhe VC, Niero R, Viana AM, Moreno FN, Campos MM, et al. Analgesic effects of callus culture from selected species of Phyllanthus. J Phar Pharmacol 1994:46:755-9.

8. Hunskaar S, Hole K. The formalin test in mice: Dissociation between inflammatory and non-inflammatory pain. Pain 1987;30:103-14.

9. Eddy NB, Leimbach D. Synthetic analgesics: II. Dithienylbutenyl and dithienylbutylamines. J Pharmacol Exp Ther 1953;107:385-93.

10. Perez, GRM, Perez LJA, Garcia DLM, Sossa MH. Neuropharmacological activity of Solanum nigrum fruit. J Ethnopharmacol 1998;62:43-8.

11. Ahmed M, Amin S, Islam M, Takahashi M, Okuyama E, Hossain CF. Analgesic principle from Abutilon indicum. Pharmazie 2000;55:314-6.

12. Ohkubo T, Shibata M. The selective capsaicin antagonist capsazepine abolishes the antinociceptive action of eugenol and guaiacol. J Dent Res 1997;76: 848-51.

13. Amico-Roxas M, Caruso A, Trombadore S, Scifo R, Scapagini U. Gangliosides antinociceptive effects in rodents. Arch Int Pharmacodyn Ther 1984;272: 103-117.

14. Raj PP. Pain mechanism. In: Raj PP, editor. Pain medicine: A comprehensive review. 1st ed. Missouri :Mosby-Year Book; 1996. p.12-23.

15. Fields HL. Analgesic drugs. In: Day W, editor. Pain. 1st ed. USA: Mac-GrawHill; 1987. p. 272.

16. Kim SS, Oh OJ, Min HY, Park EJ, Kim Y, Park HJ et al. Eugenol suppresses cyclooxygenase-2 expression in lipopolysaccharide-stimulated mouse macrophage RAW264.7 cells. Life Sci 2003;73:337-48.

17. Murakami Y, Shoji M, Hirata A, Tanaka S, Yokoe I, Fujisawa S. Dehydroisoeugenol, an isoeugenol dimer, inhibits lipopolysaccharide-stimulated nuclear factor kappa B activation and cyclooxygenase-2 expression in macrophages. Arch Biochem Biophys 2005;434:326-32. 
18. Abbot FV, Franklin KB, Westbrook RF. The formalin test scoring properties of the first and second phase of the pain response in rats. Pain 1995;60:91102.

19. Davidson EM, Carlton SM. Intraplantar injection of dextrophan, ketamine or memantine attenuates formalin induced behaviors. Brain Res 1998;785: 136-42.

20. Eisenberg E, Vos BP, Strassman AM. The NMDA antagonist memantine blocks pain behavior in a rat model of formalin induced facial pain. Pain 1993;54: 301-7.

21. Berrino L, Oliva P, Massimo F, Aurilio C, Maione S, Grella A. Antinociceptive effect in mice, of intraperitoneal $\mathrm{N}$-methyl-D-aspartate receptor antagonists in the formalin test. Eur J Pain 2003;7:131-57.

22. Brodin $P$. Differential inhibition of $A, B$, and $C$ fibres in the rat vagus nerve by lidocanine, eugenol and formaldehyde. Arch Oral Biol 1985;30:477-80.
23. Sensch O, Vierling W, Brandt W, Reiter M. Effects of inhibition of calcium and potassium currents in guinea-pig cardiac contraction: comparision of $\beta$-caryophyllene oxide, eugenol and nifedipine. Br J Pharmacol 2000;131: 1089-96.

24. Lee MH, Yeon KY, Park CK, Li HY, Fang Z, Kim MS, et al. Eugenol inhibits calcium currents in dental afferent neurons. J Dent Res 2005;84:848-51.

25. Yang BH, Piao ZG, Kim YB, Lee CH, Park K, Kim JS, et al. Activation of vanilloid receptor (VR1) by eugenol. J Dent Res 2003;82:781-85.

26. Ohkubo T, Shibata M. The selective capsaicin antagonist capsazepine abolishes the antinociceptive action of eugenol and guaiacol. J Dent Res 1997;76: 848-51.

27. Janssen PAJ, Niememegeers CJ, Dony GH. The inhibitory effects of fentanyl and other morphine-like analgesics on the warm water induced tail withdrawal reflex in rats. Arzneimittelforschung 1963;13:502-7.

\section{Theme : Emerging Horizons in Pharmacology, 21 - 23 December, 2006}

\section{Venue : S.M.S. Medical College, Jaipur (Rajasthan)}

\section{Pre Conference Workshops \\ [December 20, 2006] \\ on \\ Pharmacovigilance}

Scientific Writing for Journals, Report \& Projects.

Dr. Z.Y. Khan

Chairman
Department of Pharmacology,

Dr. Mukul Mathur

Organising Secretary

S.M.S. Medical College, Jaipur - 302 004. India.

E-mail: ipsconference@yahoo.co.in

Website: www:ipsconference.com 